\title{
HUBUNGAN ANTARA ASUPAN NUTRISI DENGAN KELANCARAN PRODUKSI ASI PADA IBU YANG MENYUSUI BAYI USIA 0-6 BULAN
}

\author{
Eny Pemilu Kusparlina \\ Akademi Kebidanan Muhammadiyah Madiun \\ Email : pemilu77@yahoo.co.id
}

\begin{abstract}
Each nursing mothers hope to breastfeed as much and as long as possible, as many (60\%) nursing mother complained her milk production is not smooth so that they add milk with infant formula. In this case the nutrients and nutrition plays an important role in terms of supporting the maximum milk production lactating mothers food guided by a balanced diet 4 healthy 5 perfect, and the number of calories as much as 2400 to 2700 calories a day. The purpose of this study was to determine the relationship between the intake of nutrients with lactation in breastfeeding mothers of infants aged 0-6 months in the village Manisrejo, Taman district Madiun City. This type of research Analytical observational using cross sectional design. population as much as 30 mothers of infants aged 0-6 months, the sampling method is simple random sampling 28 lactating mothers of infants aged 0-6 months. Independent variable is the intake of nutrients, while the dependent variable is the smoothness of milk production. Collecting data using questionnaires with a nominal scale. Data were analyzed using Fisher exact formula. The results showed that the intake of nutrients, there are 22 mothers breastfeeding mothers (78.5\%) with enough categories and 6 mothers $(21.5 \%)$ with less category. While lactation there are 23 (82\%) of mothers with milk production smoothly and there are five mothers (18\%) with less milk production category or not current. Based on the test results $p=0.0034 \leq$ $\alpha$ 0,05 so Ho rejected. Conclusion there is a relationship between the intake of nutrient with lactation. Suggestion to provide education on nutrition to breastfeeding mothers.
\end{abstract}

Keywords: Nutrition intake, milk production Smoothness

\section{PENDAHULUAN}

Makanan yang dikonsumsi pada masa menyusui harus bermutu, bergizi dan cukup kalori. Sebaiknya makanan yang mengandung sumber tenaga (energi), sumber pembangun (protein), sumber pengatur dan pelindung (mineral, vitamin, dan air). Untuk mengembalikan alat-alat kandungan ke keadaan sebelum hamil maka kebutuhan energi ibu dalam sehari adalah 2800 kalori dan protein 64 gr. Kebutuhan gizi bila menyusui akan meningkat $25 \%$. Karena berguna untuk proses kesembuhan sehabis melahirkan dan untuk memproduksi air susu yang cukup untuk menyehatkan bayi. Semua itu akan meningkat 3 kali dari kebutuhan biasa (Waryono, 2010). Kebutuhan energi ibu nifas/menyusui sebagai kebutuhan tambahan kalori pada 6 bulan pertama kira-kira $700 \mathrm{kkal} / \mathrm{hari}$ dan pada enam bulan kedua $500 \mathrm{kkal} / \mathrm{hari}$ sedangkan ibu menyusui bayi yang berumur 2 tahun rata-rata sebesar $400 \mathrm{kkal} / \mathrm{hari}$ (Ambarwati, 2010).
Produksi ASI sangat dipengaruhi oleh makanan yang dimakan ibu, apabila makanan ibu secara teratur dan cukup mengandung gizi yang diperlukan akan mempengaruhi produksi ASI, karena kelenjar pembuat ASI tidak dapat bekerja dengan sempurna tanpa makan yang cukup. Untuk membentuk produksi ASI yang baik, makanan ibu harus memenuhi jumlah kalori, protein, lemak, dan vitamin serta mineral yang cukup selain itu ibu dianjurkan minum lebih banyak kurang lebih 8-12 gelas/hari (Ambarwati, 2010). Berdiet atau menahan lapar juga melakukan pantangan makanan akan mengurangi produksi air susu ibu (Waryono, 2010).

Menurut dinas kesehatan propinsi Jawa Timur pada tahun 2017 jumlah bayi yang diberi ASI Eksklusif 245.019 (27,71\%), sedangkan seluruh jumlah bayi sebesar 867.678 bayi, untuk target tahun 2008 sebesar $60 \%$. Jumlah bayi yang diberi ASI Eksklusif tahun 2008 sebesar 278.601 (38,73\%) dengan jumlah bayi 719.332 bayi, pada tahun 2010 jumlah bayi yang diberi ASI Eksklusif sebesar 


\section{Jurnal Delima Harapan 2020}

(39,28\%). 5 Kabupaten/Kota yang telah melampaui target adalah Nganjuk, Magetan, Madiun, Mojokerto, dan Surabaya, sedangkan sisanya 33 Kabupaten/Kota masih dibawah target yang telah ditentukan.

Dari hasil pengamatan awal yang dilakukan penulis di desa Manisrejo kecamatan Taman didapatkan bahwa dari 9 ibu nifas yang diteliti didapatkan 5 ibu nifas mengkonsumsi makanan bergizi seimbang dan tidak melakukan pantangan makanan mengatakan produksi asinya baik dan lancar dan 4 ibu mengaku melakukan pantangan makanan dan tidak mengkonsumsi makanan berprotein tingggi seperti daging, mengeluh produksi ASI nya kurang lancar.

Ada beberapa faktor yang menyebabkan kurangnya produksi ASI yaitu makanan (nutrisi) ibu, ketegangan jiwa dan fikiran, penggunaan alat kontrasepsi, perawatan payudara, anatomis buah dada, faktor istirahat, faktor isapan anak, dan faktor obat-obatan. Dari faktor-faktor tersebut nutrisi mengambil peranan besar dalam produksi air susu ibu (Ambarwati, 2010).

Untuk menghindari kekurangan gizi pada ibu nifas perlu dilakukan KIE oleh petugas kesehatan tentang makanan bergizi dan yang harus dikonsumsi selama nifas, kebutuhan makanan bagi ibu nifas lebih banyak kegunaan makanan tersebut agar supaya luka-luka persalinan lekas sembuh dan bermanfaat sebagai cadangan untuk laktasi, untuk itu sebaiknya: Ibu harus teratur makan 3 kali sehari, Hidangan harus tersusun dari bahan makanan bergizi yang terdiri: makanan pokok, lauk pauk, sayuran dan buah-buahan serta diusahakan minum susu satu gelas setiap hari, Pergunakan aneka makanan yang ada. (Marmi, 2013).

\section{METODE PENELITIAN}

Penelitian ini menggunakan jenis penelitian analitik observasional. Rancangan penelitian yang digunakan dalam penelitian ini adalah Cross Sectional. (Sugiyono, 2010)

Populasi pada penelitian ini adalah ibu yang menyusui bayi usia 0-6 bulan di desa Manisrejo Kec. Taman Kota Madiun yang berjumlah 30 orang. Sampel yang digunakan dalam penelitian ini adalah $28 \mathrm{ibu}$ menyusui bayi usia 0-6 bulan di Desa desa Manisrejo Kec. Taman Kota Madiun.

$$
\begin{aligned}
& \mathrm{n}=\frac{\mathrm{N}}{1+\mathrm{N}\left(\mathrm{d}^{2}\right)} \\
& \mathrm{n}=\frac{30}{1+30\left(0,05^{2}\right)} \\
& \mathrm{n}=\frac{30}{1+30(0,0025)} \\
& \mathrm{n}=\frac{30}{1+0,075} \\
& \mathrm{n}=\frac{30}{1,075} \\
& \mathrm{n}=27,9(28)
\end{aligned}
$$

Sampel dalam penelitian ini diambil secara simple random sampling.

Variabel independen dalam penelitian ini adalah Asupan nutrisi dan variabel dependennya adalah kelancaran produksi asi. Instrumen yang digunakan untuk mengumpulkan data untuk penelitian ini adalah dengan lembar kuisioner tentang Asupan Nutrisi ibu dan kuisioner tentang kelancaran ASI.

Analisa data dalam penelitian ini meliputi analisa statistik diskriptif dan statistik inferensial. untuk statistik diskriptif menggunakan distribusi frekuensi dilengkapi persentase. Untuk membuktikan hubungan Nutrisi dengan kelancaran produksi ASI dengan menggunakan uji statistik inferensial. (Arikunto, Suharsini. 2010)

Untuk mengetahui kekuatan atau derajat hubungan dapat dilakukan dengan rumus Fisher Exact

$$
\mathrm{p}=(\mathrm{A}+\mathrm{B}) !(\mathrm{C}+\mathrm{D}) !(\mathrm{A}+\mathrm{C}) !(\mathrm{B}+\mathrm{D}) !
$$

\section{$\mathrm{N} ! \mathrm{A} ! \mathrm{B} ! \mathrm{C} ! \mathrm{D}$}

Kriteria penolakan hipotesis nol bila signifikasi diperoleh nilai $\mathrm{p} \leq 0,05$. Ho ditolak yang artinya ada hubungan antara nutrisi dengan kelancaran produksi ASI. sedangkan Bila $\mathrm{p} \geq 0,05$ berarti Ho diterima, artinya tidak ada hubungan antara asupan nutrisi dengan kelancaran produksi ASI (Sugiyono, 2011).

\section{HASIL PENELITIAN}

1. Asupan Nutrisi 


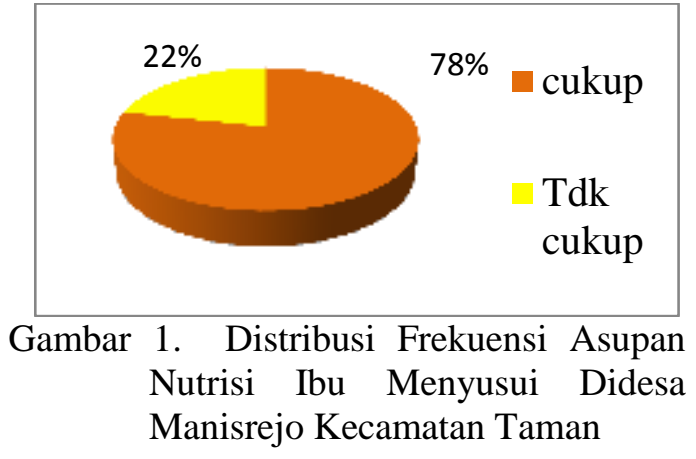

Menurut data yang dikumpulkan oleh peneliti seperti pada gambar 1 diatas didapatkan bahwa asupan nutrisi ibu menyusui dalam kategori cukup yaitu sebanyak 22 orang $(78,5 \%)$, dan untuk ibu yang asupan nutrisinya tergolong tidak cukup sebanyak 6 orang $(21,5 \%)$.

2. Kelancaran Produksi ASI

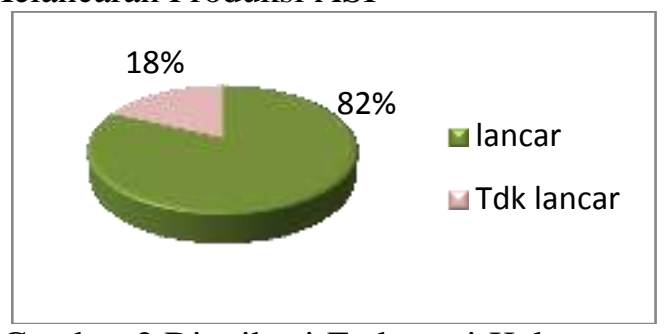

Gambar 2.Distribusi Frekuensi Kelancaran Produksi ASI Pada Ibu Menyusui Didesa Manisrejo Kecamatan Taman

Berdasarkan hasil pengumpulan data oleh peneliti seperti pada gambar 2 diatas didapatkan bahwa dari 28 responden yaitu ibu menyusui didapatkan sebagian besar ibu produksi ASI nya lancar yaitu $82 \%$ dan ibu yang ASI nya tidak lancar sebanyak $18 \%$.

3. Hubungan Asupan Nutrisi Dengan Kelancaran Poduksi ASI

Dari hasil penelitian menggambarkan bahwa dari 22 ibu menyusui yang asupan nutrisinya cukup terdapat 1 ibu yang Produksi ASI nya tidak lancar. Demikian juga dari 6 ibu menyusui yang Asupan nutrisinya kurang terdapat 2 ibu yang produksi ASI nya lancar.

Hasil uji fisher exact didapatkan nilai $\mathrm{p}$ $=0,0034$ atau nilai kemaknaan $\leq \alpha=0,05$ maka HO ditolak kesimpulannya ada hubungan antara asupan nutrisi dengan kelancaran produksi ASI di desa Manisrejo Kec. Taman Kota Madiun.

Tabel 3. Hubungan Asupan Nutrisi dengan Kelancaran produksi ASI di Desa
Manisrejo Kecamatan Taman Kota Madiun

\begin{tabular}{|c|c|c|c|c|c|c|}
\hline \multirow[t]{3}{*}{$\begin{array}{l}\text { Asupan } \\
\text { nutrisi }\end{array}$} & \multicolumn{4}{|c|}{$\begin{array}{l}\text { Kelancaran } \\
\text { Produksi ASI }\end{array}$} & \multirow{2}{*}{\multicolumn{2}{|c|}{ Jumlah }} \\
\hline & \multicolumn{2}{|c|}{ Lancar } & \multicolumn{2}{|c|}{$\begin{array}{c}\text { Tdk. } \\
\text { Lancar }\end{array}$} & & \\
\hline & $\mathrm{f}$ & $\%$ & $\mathrm{f}$ & $\%$ & $\mathrm{f}$ & $\%$ \\
\hline Cukup & 21 & 95 & 1 & 5 & 22 & 100 \\
\hline $\begin{array}{l}\text { Tidak } \\
\text { Cukup }\end{array}$ & 2 & 33 & 4 & 67 & 6 & 100 \\
\hline Jumlah & 23 & 82 & 5 & 18 & 28 & 100 \\
\hline \multicolumn{7}{|c|}{$p=0,0034 \leq \alpha 0,05$} \\
\hline
\end{tabular}

\section{PEMBAHASAN}

\section{Asupan Nutrisi}

Menurut hasil penelitian ini terdapat 78\% ibu menyusui memiliki Asupan Nutrisi Cukup dan 22\% ibu menyusui memiliki Asupan Nutrisi kurang. Hal ini menunjukkan bahwa sebagian besar ibu sudah paham tentang pemenuhan nutrsi atau kebutuhan nutrisi yang cukup untuk ibu menyusui. (Almatsier,Sunita, 2012).

Sesuai pendapat Vivian, 2010 bahwa ibu menyusui membutuhkan nutrisi yang cuckup, gizi seimbang, terutama kebutuhan protein dan karbohidarat. Ibu menyusui tidaklah terlalu ketat dalam mengatur nutrisinya, yang terpenting adalah makanan yang menjamin pembentukan ASI yang berkualitas dalam jumlah yang cukup untuk memenuhi kebutuhan bayinya Hal ini dikuatkan oleh pendapat Ambarwati 2010 Nutrisi adalah zat yang dibutuhkan untuk keperluan metabolismenya. Kebutuhan gizi pada ibu menyusui meningkat untuk produksi ASI. (Khamzah, Siti Nur. 2012)

Menurut peneliti asupan nutrisi yang baik akan mempengaruhi kualitas produk ASI dari ibu menyusui. Jadi ibu menyusui sangat membutuhkan nutrisi yang cukup untuk pertumbuhan dan perkembangan bayi.

2. Kelancaran Produksi ASI

Dalam penelitian ini terdapat $82 \%$ ibu menyusui yang memiliki ASI lancar sedangkan ibu yang memiliki ASI tidak lancar ada $18 \%$ dari total 28 ibu menyusui yang ada didesa Manisrejo.

Dari kebanyakan ibu menyusui tidak melakukan pantangan makanan sehingga hal tersebut. Sesuai dengan teori kelancaran 
produksi ASI menurut Pusdiknakes yaitu salah satu faktor yang mempengaruhi produksi ASI adalah makanan yang dimakan oleh ibu. Makanan yang dikonsumsi ibu menyusui sangat berpengaruh terhadap produksi ASI. (Sri Purwati, huberti. 20140). Apabila makanan yang ibu makan mengandung cukup gizi dan pola makan yang teratur, maka produksi ASI akan berjalan dengan lancar, selain makanan ada beberapa faktor lain yang mempengaruhi kelancaran produksi ASI seperti yang dijelaskan oleh Vivian 2010 terdapat faktor-faktor yang mempengaruhi produksi ASI yaitu Asupan nutrisi, kesehatan jiwa dan fikiran, penggunaan alat kontrasepsi dan anatomi payudara.

Menurut peneliti kelancaran produksi ASI sangat dipengaruhi oleh makanan yang dikonsumsi oleh ibu, sehingga ibu menyusui sangat membutuhkan makanan yang bergizi dan seimbang untuk bisa menghasilkan ASI yang produktif.

3. Hubungan Antara Asupan Nutrisi dengan kelancaran Produksi ASI

Pada dasarnya Nutrisi memang dibutuhkan tidak hanya dalam proses kelancaran produksi ASI tapi juga dibutuhkan dalam siklus kehidupan. Hubungan asupan nutrisi dengan produksi ASI pada ibu yang menyusui bayi umur 0-6 bulan di Manisrejo kecamatan Taman Kota Madiun. Hasil uji fisher exact didapatkan nilai $\mathrm{p}=0,0034$ atau nilai kemaknaan $\leq \alpha=$ 0,05 maka HO ditolak, sehingga dapat disimpulkan bahwa ada hubungan antara asupan nutrisi dengan produksi ASI pada ibu yang menyusui bayi umur 0-6 bulan. Hal ini dapat diartikan bahwa ibu yang memberikan ASI dengan asupan nutrisi yang baik maka produksi ASI nya lebih baik daripada ibu yang memberikan ASI yang asupan nutrisinya kurang maka produksi ASI nya juga kurang lancar. (Kristiyansari,Weni. 2009)

Hasil penelitian dar Prasetyono (2009) bahwa pembentukan air susu ibu salah satunya dipengaruhi oleh hormon prolaktin. Hormon prolaktin merupakan hormon utama yang mengendalikan dan menyebabkan keluarnya air susu ibu. Hormon ini mengatur sel-sel dalam alveoli agar memperoduksi air susu. Pengeluaran hormon prolaktin akan terhambat apabila ibu dalam keadaan nutrisi ibu yang buruk. Apabila nutrisi ibu baik maka akan memacu sekresi prolaktin yang akan merangsang adenohipofise (hipofise anterior) sehingga keluar prolaktin.

Hasil penelitian ini sesuai dengan pendapat Jannah (2012) bahwa gizi seimbang pada saat menyusui merupakan kebutuhan yang sangat penting bagi ibu yang menyusui. Nutrisi pada ibu menyusui sangat erat kaitannya dengan produksi ASI, yang sangat dibutuhkan untuk tumbuh kembang bayi. Ibu menyusui tidaklah terlalu ketat dalam mengatur nutrisinya, yang terpenting adalah makanan yang menjamin pembentukan ASI yang berkualitas dalam jumlah yang cukup untuk memenuhi kebutuhan bayinya.

\section{KESIMPULAN}

Berdasarkan hasil analisa data penelitian yang telah dilakukan di Desa Manisrejo, Kecamatan Taman Kota Madiun, maka dapat disimpulkan ada hubungan antara Asupan Nutrisi dengan kelancaran Produksi ASI.

\section{REFERENSI}

Almatsier,Sunita, 2012. Prinsip Ilmu Gizi Dasar. Gramedia: Jakarta

Ambarwati dkk. 2010. Asuhan Kebidanan Nifas. Nuha Medika: Yogyakarta

Arikunto, Suharsini. 2010. Prosedur Penelitian. Rineka Cipta: Jakarta

Jannah, N.2012.Buku Ajar Asuhan Kebidanan :kehamilan. CV Andi OF SET :Yogyakarta.

Khamzah, Siti Nur. 2012. Segudang Keajaiban Asi Yang Harus Anda Ketahui. Flashbook. Yogjakarta

Kristiyansari,Weni. 2009. Asi Menyusui dan Sadari. Nuha Medika: Yogjakarta

Marmi. 2013. Gizi Dalam Kesehatan Reproduksi. Pustaka Pelajar: Yogyakarta

Prasetyono, D.S., 2009. ASI Eksklusif Pengenalan,Praktik dan Kemanfaatankemanfaatannya. Diva Press : Yogyakarta

Roesli, Utami. 2015. Mengenal ASI EKSKLUSIF.EGC: Jakarta

Soetjiningsih. 2013. ASI: Petunjuk untuk Tenaga Kesehatan. EGC: Jakarta 
Sri Purwati, huberti. 2014. Konsep Penerapan Asi Eksklusif.EGC: Jakarta

Sugiyono. 2010. Statistika Untuk Penelitian. Alfabeta: Bandung

Sugiyono.2011. metodologi penelitian kuantitatif, kualitatif dan kombinasi (Mixed methods). Bandung: Alfabeta

Vivian dkk. 2011. Asuhan Kebidanan Pada Ibu Nifas. Salemba Medika: Yogyakarta

Waryono. 2010. Gizi Reproduksi. Pustaka Rihama: Yogyakarta. 